\title{
Problem dan Solusi Studi Mahasiswa Semester Tua
}

\author{
Raharjo \\ IAIN Walisongo Semarang \\ E-mail: joe.raharjo65@yahoo.co.id
}

\begin{abstract}
This paper describes the problems of old-semester students in completing their study at the Faculty of Science of Islamic Education and Teaching (FITK) IAIN Walisongo Semarang. The study of exploratory qualitative approach involves 20 students from all courses taken by purposive random sampling with the technique of questionnaires, interviews and documentations. The results are: (1) The problems faced by elderly semester students is a matter of academic and nonacademic, namely working part time, participating organizations, teaching and unwarranted. (2) The problems are handled by the leaders of the faculty involved: (a) anticipatory since the beginning of their study and academic orientation; (b) preventing for their study by the lecturer as supervisor; and (c) curating towards the end of the study by the head of the faculty. These steps are performed in order to provide opportunities for students to be able to pass and not threatened to drop out.
\end{abstract}

Keywords: delayed study, old students, solutions, anticipatory, preventive and curative

\begin{abstract}
Abstrak
Paper ini menjelaskan permasalahan mahasiswa semester tua dalam menyelesaikan studinya di Fakultas Ilmu Tarbiyah dan Keguruan (FITK) IAIN Walisongo Semarang. Kajian dengan pendekatan kualitatif eksploratif ini melibatkan 20 mahasiswa dari semua program studi yang diambil secara purposive random sampling dengan teknik angket, wawancara, dokumentasi. Hasilnya adalah bahwa: (1) Mahasiswa semester tua menghadapi masalah akademik dan nonakademik berupa kuliah kerja, ikut organisasi, mengajar dan tidak beralasan. (2) Penanganan yang dilakukan pimpinan lembaga meliputi: (a) antisipatif sejak awal masa studi dan orientasi akademik; (b) preventif selama studi oleh dosen pembimbing; dan kuratif menjelang akhir studi oleh pimpinan lembaga. Langkah-langkah ini dilakukan dalam rangka memberikan peluang kepada mahasiswa agar bisa lulus dan tidak terancam drop out.
\end{abstract}

Kata kunci: keterlambatan studi, mahasiswa semester tua, solusi, antisipatif, preventif dan kuratif 


\section{A. Pendahuluan}

Pencapaian tujuan merupakan standar keberhasilan suatu usaha, sehingga setiap usaha yang dilakukan berdasarkan tujuan tertentu, pasti ditargetkan untuk mencapai tujuan tersebut. Dalam konteks pendidikan, keberhasilan itu didasarkan pada standar kelulusan yang kemudian kita kenal dengan istilah output. Standar keberhasilan pendidikan di perguruan tinggi ditandai dengan perolehan skor lulus pada tiap mata kuliah. Skor-skor tersebut diakumulasikan dan di rata-rata menjadi indeks prestasi (IP). IP untuk satu semester disebut IP semester, sedangkan IP selama masa studi yang sudah ditempuh disebut IP kumulatif.

Target selesainya masa studi secara teoritis tersebut memberikan kesan bahwa kuliah itu ringan dan memang dapat diselesaikan selama 8 semester. Dikatakan ringan, karena dengan mengambil beban studi 20 SKS dalam satu semester, beban belajar per Minggu hanya 10 kali tatap muka. Jika sehari ada 3 kali tatap muka, misalnya jam pertama hingga jam ketiga (mulai jam 07:00 hingga jam 11:50), maka tiap pekan hanya diperlukan 4 hari untuk memenuhi kuliah tatap muka di kelas. Sisa waktunya dapat digunakan untuk belajar mandiri (kurikuler, kokurikuler dan/ekstrakurikuler), kegiatan lain, atau bahkan dapat digunakan untuk kerja casual (sambilan). Dengan demikian, pengambilan beban studi 20 SKS per semester tersebut sebenarnya tidak semata-mata didasarkan pada kemampuan kognitif (IQ) mahasiswa, namun lebih didasarkan pada rencana kuliah yang dipadu dengan kegiatan-kegiatan lainnya.

Kenyataan di lapangan, banyak mahasiswa pada semester 2 sampai 6, mengambil mata kuliah 24 SKS, dengan demikian, secara teoritis, beban studi mereka pada semester 7 dan 8 sangat ringan, namun tetap saja ada di antara mereka yang menyelesaikan studinya lebih dari 5 tahun. Di sisi lain, sebagian mahasiswa yang lulus hingga semester 12, memang sudah mengatur beban belajarnya sedemikian rupa. Di samping belajar, mereka aktif di kegiatan ekstra kurikuler atau sambil bekerja. Dengan demikian, secara umum mahasiswa yang masa studinya melebihi 10 semester dimungkinkan memiliki kendala. Kendala tersebut tentunya kendala nonakademik, sebab jika mahasiswa tersebut mengalami kendala akademik, kemungkinan sudah terkena DO (drop out) pada akhir semester dua dengan perolehan IP kumulatif 
di bawah 2,0 atau dengan sendirinya keluar akibat ketidakmampuan menyelesaikan tugas-tugas akademik. ${ }^{1}$

Pertanyaannya adalah mengapa masih ada mahasiswa yang masa studinya melebihi semester 10? Masalah apa yang mereka hadapi? Solusi apa yang bisa diberikan, agar mereka tidak melewati batas maksimal masa studinya? Inilah fenomena yang menarik untuk dilakukan penelitian, agar diperoleh solusi terbaik guna membantu kelancaran studi dan peningkatan kualitas prestasi mahasiswa.

\section{B. Keterlambatan Studi Di Perguruan Tinggi}

1. Kajian Teori

Masa studi S.1 diberi waktu paling lama 14 semester dengan beban studi maksimal 160 sks. Secara praktis, beban studi tersebut dapat diselesaikan selama 9 semester, sebagaimana deskripsi di atas, dengan wisuda di semester 10 . Dengan demikian mahasiswa yang menyelesaikan studi lebih dari semester 10 dapat dikategorikan mahasiswa dengan problem 'keterlambatan studi'.

Definisi problem keterlambatan studi tersebut diperkuat dengan Permendikbud Nomor 49 Tahun 2014 tentang Standar Nasional Pendidikan Tinggi yang mengatur S1 dengan beban studi 144 SKS (Pasal 17) dan masa usia studi 4-5 tahun. ${ }^{2}$ Isi Permendikbud tersebut dapat dipahami bahwa mahasiswa S1 yang masa studinya lebih dari 5 tahun, dapat dikatakan terlambat. Dengan kata lain, mereka yang masa studinya berada di semester 11 sampai dengan 14 termasuk mahasiswa semester tua, sebagaimana topik penelitian ini.

a. Problem Studi di Perguruan Tinggi

Studi di perguruan tinggi merupakan salah satu citacita siswa-siswi SMA/sederajat. Studi di perguruan tinggi dibedakan dari studi di tingkat pendidikan yang lebih rendah (sekolah/ madrasah) didasarkan pada tiga aspek, yaitu: usia peserta didik, tujuan belajar dan lama belajarnya. Usia peserta didik berada pada rentang usia

${ }^{1}$ IAIN Walisongo, Buku Panduan Program Sarjana (S.1) dan Diploma 3 (D.3), tahun akademik 2013-2014, hlm.177-178.

2 Permendikbud Nomor 49 Tahun 2014 tentang Standar Nasional Pendidikan Tinggi. 
dewasa, karenanya sistem pembelajaran di perguruan tinggi menggunakan model andragogi. Tanggung jawab belajar hampir sepenuhnya dipercayakan kepada mahasiswa, sedangkan dosen hanya memberikan dasardasar pengetahuan saja.

Tujuan belajar di perguruan tinggi adalah untuk memantapkan mahasiswa menjadi seorang pekerja di kemudian hari yang lebih terampil dan profesional. Untuk memberikan keleluasaan dan fleksibilitas beban dan aktivitas kuliah, maka diberlakukan sistem kredit semester (sks). Lama belajar di perguruan tinggi untuk program S-1 dan D-IV adalah antara 8 semester (4 tahun) hingga 14 semester (7 tahun) dengan beban studi 144-160 sks. Aturan baru tentang lama belajar di perguruan tinggi untuk program S-1 dan D-IV adalah 4-5 tahun. ${ }^{3}$

Pada awalnya, para alumni SMA berusaha semaksimal mungkin bisa diterima di Perguruan Tinggi Negeri. Berbagai jalur diikutinya, dari seleksi nasional, tes nasional, hingga jalur mandiri di perguruan tinggi masing-masing. Lebih-lebih dengan diberlakukannya UKT (uang kuliah tunggal), biaya kuliah di perguruan tinggi negeri favorit bukan satu hal yang menghantui. Mereka yang tidak diterima di PTN, dapat masuk di PTS (perguruan tinggi swasta) yang jumlah program studinya lebih banyak dan kualitasnya tidak selalu lebih rendah dari program studi di PTN. ${ }^{4}$

Sebagai mahasiswa baru, mereka melangkahkan kaki menuju kampus dengan bangga dan semangat, serta berharap dapat menyelesaikan kuliah dengan cepat untuk segera menjadi seorang sarjana atau seorang profesional dalam bidang tertentu. Setelah beberapa Minggu mengikuti perkuliahan, mereka merasakan ternyata belajar di Perguruan Tinggi tidaklah semudah yang

${ }^{3}$ Permendikbud Nomor 49 Tahun 2014 tentang Standar Pendidikan Tinggi, Pasal 17 poin 3.

${ }_{4}$ Peraturan Menteri Pendidikan dan Kebudayaan (Permendikbud) No. 55 Tahun 2013 tertanggal 23 Mei 2013, tentang Biaya Kuliah Tunggal (BKT) dan Uang Kuliah Tunggal (UKT) pada Perguruan Tinggi Negeri (PTN) di lingkungan Kementerian Pendidikan dan Kebudayaan (Kemdikbud). 
mereka bayangkan. Mereka harus mengikuti perkuliahan dengan tertib, rajin membaca literatur-literatur yang mungkin berbahasa asing, memahami berbagai macam teori, mengerjakan tugas-tugas, menyusun makalah, presentasi, berdiskusi dan sebagainya.

Mahasiswa yang kurang cepat beradaptasi dengan atmosfer perguruan tinggi sering merasa kurang siap menghadapi tugas-tugas akademiknya (sehingga dianggap sebagai beban atau masalah yang sangat berat), yang bisa berakibat pada perolehan skor rendah (atau bahkan tidak lulus) pada satu atau beberapa mata kuliah. Masalah-masalah lainnya yang dapat dipersepsikan amat beragam, antara lain: mata kuliah tertentu dianggap asing, susah memahami literatur, lambat menyelesaikan tugas, menyusun makalah tidak sempurna, berbicara di kelas ditertawakan temannya. Efeknya bisa tidak kerasan kuliah di suatu program studi (prodi) dan ingin pindah ke lain prodi, lulus tidak tepat waktu (lebih dari 5 tahun), lulus tidak cumlaude, lulus dengan IP pas-pasan, ataupun lulus tapi tidak segera mendapat pekerjaan. ${ }^{5}$ Dalam aturan baru, masa studi di perguruan tinggi (S-1 dan DIV) dibatasi paling lama 5 tahun. ${ }^{6}$ Walaupun masih banyak mendapat respons negatif dari berbagai perguruan tinggi. ${ }^{7}$ Terutama dari perguruan tinggi swasta. ${ }^{8}$

b. Strategi Studi di Perguruan Tinggi

Dalam menghadapi rangkaian masalah studi di perguruan tinggi, mahasiswa memerlukan strategi tertentu agar dapat mengatur waktu, dana, tenaga, kegiatan, fasilitas, dan penyelesaian studinya. Strategi

${ }^{5}$ Daniel Mohammad Rosyid, Sukses Kuliah di Perguruan Tinggi, Siapa Takut?, (http:// danielrosyid. com/ buku-baru-sukses-kuliah-di-perguruantinggi-siapa-takut.html), Diakses 10 Januari 2015.

${ }^{6}$ Permendikbud Nomor 49 Tahun 2014 tentang Standar Pendidikan Tinggi, Pasal 17 poin 3.

7 Edzan Raharjo, Masa Kuliah Dibatasi Maksimal hanya 5 Tahun, Mahasiswa UGM Unjuk Rasa, (http://news.detik.com/read/2014/09/16/ 125853/2691572/10/masa-kuliah-dibatasi-maksimal-hanya-5-tahunmahasiswa-ugm-unjuk-rasa), diakses 16 September 2014.

${ }^{8}$ Hendy Kurniawan, Kuliah Dibatasi Hanya 5 Tahun, (http://jogja. tribunnews.com /2014/ 09/05/kuliah-dibatasi-hanya-5-tahun/), diakses 05 September 2014. 
tersebut dilandasi dengan semangat, tekun dan giat belajar agar dapat mencapai tujuan yang ditetapkan sebelumnya. ${ }^{9}$ Satu strategi kuliah yang dapat diaplikasikan oleh mahasiswa adalah sistem belajar "MURDER" dari buku The Complete Problem Solver oleh Bob Nelson. ${ }^{10}$ Istilah tersebut dijabarkan dalam beberapa kata yakni: Mood-Understand-Recall-DigestExpand-Review. Setiap mahasiswa harus menciptakan perasaan senang (mood) setiap kali menerima materi kuliah. Setiap catatan perlu diberi tanda pada kalimat atau kata yang tidak dapat dipahami, lalu dicari jawaban dan penjelasannya melalui sumber-sumber lain untuk meningkatkan pemahaman (understand).

Materi yang telah dipelajari perlu diulang (recall) secara kontinu, baik dengan cara membuat rangkuman dengan kata-kata sendiri ataupun menggunakan kata kunci dari setiap kalimat yang panjang. Rangkuman yang telah dibuat perlu ditelaah kembali (digest) dan apabila kurang jelas bisa mencari penjelasan lebih lanjut dari dosen atau sumber lainnya atau berdiskusi dengan teman. Materi yang telah dipelajari perlu dikembangkan (expand) dan diterapkan dalam kehidupan diri sendiri. Lalu didiskusikan dengan teman atau dosen berdasarkan catatan dan atau materi yang dipelajari sebelumnya. Materi-materi yang telah dipelajari harus dipelajari kembali (review) dan jangan pernah bosan untuk mengulang materi yang sudah dibaca agar semakin mudah diingat dan dipahami.

Strategi lainnya yang berdampak pada pencapaian prestasi akademik bagi mahasiswa dalam proses belajarnya adalah: (1) Jadwal perlu disusun dengan cermat dalam melakukan setiap kegiatan, agar tidak membuang-buang waktu. (2) Setiap mahasiswa harus belajar untuk membuat tujuan kegiatan akademik dan menjalankan tujuan tersebut dengan strategi tepat. (3)

9 Aty Nurdiana, Cara Belajar di Perguruan Tinggi, (http://lentera stkippgribl.blogspot.Com/2013/02/cara-belajar-di-perguruan-tinggi.html), diakses 11 Januari 2014.

10

http://www.nyit-nyit.net/topic/55025-cara-belajar-efektif-diperguruan-tinggi/ 
Kegiatan pembelajaran harus ditempatkan sebagai prioritas utama, baru untuk kegiatan yang lain. (4) Mahasiswa harus menghadiri setiap kegiatan kuliah dari awal hingga akhir. (5) Tiap mahasiswa harus dapat meluangkan waktu untuk belajar secara efektif dengan mendalami materi yang telah dipelajari dan mempelajari ulang, secara mandiri atau kelompok. (6) Membina hubungan dengan pembimbing akademik dengan komunikasi rutin yang efektif akan membantu memperlancar proses pembelajaran. ${ }^{11}$ (7) Setiap dosen memiliki sifat, sikap dan karakter, yang berbeda dengan dosen yang lain, dan mahasiswa perlu memahami dosennya masing-masing. (8) Mahasiswa perlu memahami dan mematuhi peraturan dan kebijakan perguruan tinggi. (9) Sarana dan prasarana kampus disediakan untuk mendukung proses dan pelayanan kegiatan akademik, untuk itu mahasiswa perlu memahami ketersediaannya, dan dapat memanfaatkannya secara optimal. (10) Kegiatan nonakademik sangat berperan dalam mengembangkan bakat dan kepribadian. Kegiatan nonakademik disediakan untuk mahasiswa guna mempersiapkan peran sosialnya di masyarakat. Peranan sosial mahasiswa dan pemuda di masyarakat, kurang lebih sama dengan peran warga yang lainnya di masyarakat. $^{12}$

c. Faktor yang Mempengaruhi Keberhasilan Kuliah

Beberapa tokoh (Dimyati Mahmud, Rooijakkers, Ngalim Purwanto), mengatakan bahwa faktor-faktor yang mempengaruhi prestasi belajar siswa secara umum dapat dibagi dua yakni faktor internal dan faktor eksternal. ${ }^{13}$

1) Faktor Internal

${ }^{11}$ Aghnia, Strategi Belajar Di Perguruan Tinggi, (http://aghnia-rahmah. blogspot. com/2011/10/ strategi-belajar-di-perguruan-tinggi.html), diakses: 10 Januari 2015.

12 Abdul Hakim, Memahami \& menghayati masalah-masalah kepemudaan, sebagai pemuda yang sedang belajar di perguruan tinggi, (http://alhakiiim.blogspot.com/2012/11/memahami-menghayati-masalahmasalah_13.html), diakses 10 Januari 2015.

13 Ngalim Purwanto, Psikologi Pendidikan, (Bandung: Remaja Rosdakarja, 1990), hlm. 270. 
Faktor internal adalah faktor yang berasal dari dalam diri siswa itu sendiri. Faktor ini meliputi biologi, fisiologi dan psikologi. ${ }^{14}$ Faktor biologi berupa bakat, minat, dan kecerdasan yang diturunkan secara genetik dari orang tuanya dan sifatnya relatif permanen. Faktor fisiologi berupa kondisi fisik dan pancaindra. 15 Sedangkan faktor psikologi mencangkup (a) need for achievement yaitu kebutuhan atau dorongan atau motif untuk berprestasi, (b) interest yakni minat terhadap sesuatu, dan (c) capability, berupa bakat dan kecerdasan seperti kemampuan memusatkan perhatian pada materi perkuliahan yang berlangsung, tingkat penerimaan dan pengingatan bahan, kemampuan menerapkan apa yang dipelajari, kemampuan mereproduksi dan kemampuan menggeneralisasi.

Ada empat modal utama yang mempengaruhi keberhasilan studi di perguruan tinggi, yaitu: citacita, minat, percaya diri dan kebebasan jiwa. Setiap mahasiswa yang belajar di Perguruan Tinggi harus didukung oleh cita-cita tertentu, sehingga ia tahu tujuan yang harus dicapai dan tahu untuk apa ia belajar. Seorang mahasiswa harus mempunyai minat tinggi terhadap setiap mata kuliah yang diikuti, agar ia merasa senang dalam mengikuti perkuliahan sehingga dapat berkonsentrasi dan memperkecil kegagalan. Mahasiswa harus memiliki rasa percaya diri bahwa ia tidak berbeda dengan teman-temannya, sehingga tidak minder. Di samping itu mahasiswa juga harus memiliki kebebasan jiwa, yang memungkinkan dia terbebas dari pengaruh sentimen dan emosi, dan tetap memiliki sikap ilmiah dan dapat berpikir kritis. ${ }^{16}$ 84-87.

${ }^{14}$ M.D. Mahmud, Psikologi Pendidikan, (Jakarta: PPLPTK, 1989), hlm.

15 A. Rooijakers, Mengajar dengan Sukses, terj. Soenoro, (Jakarta: Gramedia,1982), hlm. 30.

16 Aty Nurdiana, Cara Belajar di Perguruan Tinggi, (http://lenterastkippgribl. blogspot. Com /2013/02/cara-belajar-di-perguruantinggi.html), diakses 11 Januari 2015. 
Faktor-faktor internal tersebut berujud dalam bentuk gaya belajar, yang tentunya berbeda dengan gaya belajar siswa di SLTA. ${ }^{17}$ Mahasiswa dituntut untuk mampu belajar mandiri baik secara individual maupun kelompok dalam perkuliahan, dan mengusai sumber-sumber informasi dan perkuliahan baik di perpustakaan maupun internet. Mahasiswa harus mampu mendisiplinkan diri untuk belajar baik di rumah atau kos dan di kampus. Belajar kelompok akan memberikan percepatan belajar karena ada interaksi sesama mahasiswa. Sebelum perkuliahan, mahasiswa harus sudah mempersiapkan diri baik mental maupun kesiapan mempelajari bahan perkuliahan. Selama perkuliahan mahasiswa harus mampu untuk aktif dalam berinteraksi dengan mahasiswa lainnya maupun dengan dosen. ${ }^{18}$

2) Faktor Eksternal

Faktor eksternal adalah faktor yang berasal dari luar diri mahasiswa. Faktor ini meliputi: (a) lingkungan alam dan sosial baik itu lingkungan keluarga, kampus maupun masyarakat, dan (b) instrumentasi yang berupa kurikulum, dosen, sarana dan fasilitas serta administrasi.

Faktor dominan di lingkungan kampus adalah dosen, mahasiswa dan pegawai. Mahasiswa harus bisa menjaga dan membina hubungan baik dengan dosen. Hubungan ini akan menambah kualitas interaksi akademik dalam upaya menambah dan memperdalam wawasan dan pengetahuan baik dalam bidang akademik maupun nonakademik. Dosen dapat berperan sebagai pejabat struktural, pembimbing akademik, pembimbing kemahasiswaan, pembimbing kegiatan praktek lapangan dan sebagai pengajar. Oleh karena itu, mahasiswa perlu menyesuaikan diri dengan setiap

17 Abdul Muiz Lidinillah, Strategi Belajar di Perguruan Tinggi (PT), (http://dindin-abdulmuiz. blogspot. Com /2008/09/strategi-belajar-diperguruan-tinggi-pt.html), diakses 10 Januari 2015.

${ }^{18}$ IAIN Walisongo, Buku Panduan Program Sarjana (S.1) dan Diploma 3 (D.3), tahun akademik 2013-2014, hlm.71 
peran dari dosen tersebut demi keberhasilan kuliahnya. $^{19}$

Keaktifan dalam kegiatan kemahasiswaan merupakan sarana pendukung untuk membina hubungan sosial mahasiswa dengan mahasiswa. Sejak mulai menjadi mahasiswa baru, mahasiswa sudah dapat melibatkan diri dalam setiap kegiatan kemahasiswaan. Dimulai dengan kegiatan orientasi pengenalan kampus, hingga kegiatan ekstra kurikuler serta kegiatan-kegiatan di luar kampus, kesemuanya untuk menambah horizon pengalaman mahasiswa. Pemilihan jenis kegiatan nonakademik bisa berpengaruh (positif-negatif) terhadap studi.

Sebagian mahasiswa berhasil membagi waktu dengan kegiatan kuliah, sebagian lain terganggu kuliahnya. Namun, ada juga mahasiswa yang tidak mendapatkan sesuatu dari beraktivitas dalam kegiatan kemahasiswaan. Sebelum menentukan pilihan kegiatan tersebut, mahasiswa harus terlebih dahulu memahami tujuan untuk aktif, bisa didasarkan pada minat dan bakat atau karena tujuan untuk mengembangkan diri dalam bidang organisasi. Mahasiswa harus terlebih dahulu memahami segala konsekuensi ke depan baik dari segi waktu, biaya atau pengaruhnya terhadap tugas kuliah.

Mahasiswa akan sering berinteraksi dengan masyarakat baik di dalam maupun di luar kampus. Di kampus ada pegawai administrasi sebagai pihak yang berperan dalam memperlancar prosedurprosedur akademik, juga warga kampus lainnya seperti pedagang. Masyarakat di luar kampus seperti di lingkungan tempat tinggal menjadi bagian yang sering membantu kelancaran studi di perguruan tinggi. Pemilihan tempat kos atau asrama hendaknya yang strategis dilihat dari kondusif tidaknya terhadap kegiatan belajar. Mahasiswa dapat berinteraksi

\footnotetext{
${ }^{19}$ Abdul Muiz Lidinillah, Strategi Belajar di Perguruan Tinggi (PT), (http://dindin-abdulmuiz.blogspot.com/2008/09/strategi-belajar-diperguruan-tinggi-pt.html), diakses 10 Januari 2015.
} 
secara luas dengan masyarakat selama menunjang pada program perkuliahan dan membantu dalam pengembangan diri mahasiswa.

Deskripsi di atas menunjukkan bahwa problem belajar di perguruan tinggi dapat dibedakan menjadi dua yakni problem akademik dan nonakademik. Problem akademik adalah problem yang terkait dengan aktivitas kuliah mencakup perencanaan, proses dan hasil.. Problem nonakademik adalah problem di luar aktivitas kuliah, tetapi terkait dengan keseluruhan proses pembentukan sikap, kepribadian dan perilaku mahasiswa sebagai bagian dari tujuan pendidikan di perguruan tinggi. Masalah nonakademik tersebut antara lain keuangan, asmara, keluarga, sosial, dan karier.

2. Kajian Hasil Penelitian Sebelumnya

Aditya Sukma, Studi Empiris Pengaruh Kecerdasan Emosional, Perilaku Belajar, dan Stres Kuliah terhadap Keterlambatan Penyelesaian Studi (Studi pada Mahasiswa S1 Akuntansi Universitas Brawijaya Malang). ${ }^{20}$ Penelitian ini dimaksudkan untuk mencari jawaban atas fenomena lama penyelesaian studi dan keterkaitannya dengan variabel kecerdasan emosional, perilaku belajar, dan tingkat stres mahasiswa. Populasi penelitian ini adalah mahasiswa Jurusan Akuntansi Universitas Brawijaya Malang, yang telah menempuh masa studi lebih dari 4 tahun (8 semester). Teknik pengambilan sampel menggunakan purposive sampling. Data penelitian diperoleh melalui kuesioner.

Penelitian ini dilakukan dengan menggunakan analisis regresi linear berganda. Hasil penelitian menunjukkan bahwa variabel perilaku belajar dan stres kuliah berpengaruh signifikan terhadap keterlambatan penyelesaian studi, sedangkan variabel kecerdasan emosional tidak berpengaruh secara signifikan.

${ }^{20}$ A. Sukma, Studi Empiris Pengaruh Kecerdasan Emosional, Perilaku Belajar, dan Stres Kuliah terhadap Keterlambatan Penyelesaian Studi (Studi pada Mahasiswa S1 Akuntansi Universitas Brawijaya Malang), http://jimfeb.ub.ac.id/index.php/jimfeb/article/view/707/649, diakses 1 Oktober 2014. 
Yahdinil Firda Nadirah (2011), Hubungan Antara Stres dan Bersyukur dengan Keterlambatan Penyelesaian Studi pada Mahasiswa (Studi pada Mahasiswa yang Mengalami Keterlambatan Penyelesaian Studi di Fakultas Tarbiyah IAIN "SMH" Banten). ${ }^{21}$ Sampel penelitian ini berjumlah 30 orang mahasiswa IAIN "SMH" Banten di lingkungan Fakultas Tarbiyah yang berada pada semester 9 atau lebih, yang diperoleh berdasarkan teknik purposive sampling.

Berawal dari penelitian, ditemukan adanya hubungan yang signifikan antara stres dan keterlambatan penyelesaian studi mahasiswa sebesar $\mathrm{p}=0.023(\overline{\mathrm{p}} 0.05)$. Semakin tinggi stres yang dialami seorang mahasiswa maka semakin terlambat penyelesaian studinya. Sementara tidak ditemukan adanya hubungan yang signifikan antara bersyukur dengan keterlambatan penyelesaian studi pada mahasiswa. Dan hipotesis yang menyatakan adanya kontribusi yang positif dan signifikan antara kedua variabel (stres dan bersyukur) dengan keterlambatan penyelesaian studi pada mahasiswa, ditolak. Kedua variabel tersebut (stres dan bersyukur) secara bersama-sama tidak memberikan kontribusi yang signifikan terhadap keterlambatan penyelesaian studi pada mahasiswa.

Anis Ardiana Kurniawati (2011), Analisis ProblemProblem Keterlambatan Penyelesaian Studi Mahasiswa di STAIN Salatiga (Studi Kasus Mahasiswa Program Studi Pendidikan Agama Islam Tahun Ajaran 2004 dan 2005). ${ }^{22}$ Permasalahan yang diteliti adalah faktor-faktor

21 Y.F. Nadirah, Hubungan Antara Stres dan Bersyukur dengan Keterlambatan Penyelesaian Studi pada Mahasiswa (Studi pada Mahasiswa yang Mengalami Keterlambatan Penyelesaian Studi di Fakultas Tarbiyah IAIN "SMH" Banten), http://iainbanten.ac.id/berita-314-hubungan-antarastress-dan-bersyukur-dengan-keterlambatan-penyelesaian-studi-padamahasiswa.html, diakses 1Oktober 2014.

22 A.A. Kurniawati, Analisis Problem-Problem Keterlambatan Penyelesaian Studi Mahasiswa di STAIN Salatiga (Studi Kasus Mahasiswa Program Studi Pendidikan Agama Islam Tahun Ajaran 2004 dan 2005), http://eprints.stainsalatiga.ac.id/659/1/ANALISIS\%20PROBLEM-

PROBLEM\%20KETERLAMBATAN\%20 PENYELESAIAN\%20STUDI\% 20-STAIN\%20SALATIGA.pdf, diakses 1 Oktober 2014. 
penyebab keterlambatan dan solusi untuk mengatasi permasalahan keterlambatan penyelesaian studi. Penelitian ini menggunakan pendekatan kualitatif deskriptif, sedangkan pengumpulan datanya menggunakan metode wawancara dan dokumentasi.

Hasil penelitian menunjukkan bahwa pada faktor eksternal problem yang dialami oleh mereka adalah ekonomi keluarga, sedangkan pada faktor internal problem yang dialami adalah inteligensi, kepribadian, minat sekolah, adaptasi, sifat dan motivasi. Solusi untuk mengatasi permasalahan tersebut di atas bersumber dari alumni mahasiswa Program Studi PAI tahun ajaran 2006 dan beberapa dosen serta pejabat STAIN Salatiga yang berkecimpung pada Program Studi Pendidikan Agama Islam (PAI).

\section{Metode Penelitian}

Penelitian ini menggunakan metode penelitian kualitatif eksploratif. Di mana peneliti melakukan penjajakan terhadap kondisi mahasiswa yang masuk semester tua (semester 12 dan 14) di Fakultas Ilmu Tarbiyah dan Keguruan (FITK) IAIN Walisongo Semarang. Metode ini dapat memberikan sebuah gambaran mengenai kondisi yang terjadi sebenarnya oleh mahasiswa, apa saja yang dialami selama menjadi mahasiswa, termasuk mencari jalan keluar terhadap persoalan yang ada. ${ }^{23}$

Data mahasiswa semester 12 dan 14 yang tercatat sebagai mahasiswa aktif di IAIN Walisongo pada semester gasal 20132014 berjumlah 308, dengan rincian sebagai berikut:

\begin{tabular}{lccc}
\hline \multirow{2}{*}{ Fakultas } & Masuk Th 2007 & Masuk Th 2008 & \multirow{2}{*}{ Jumlah } \\
\cline { 2 - 3 } & SMT 14 & SMT 12 & \\
\hline FDK & 17 & 42 & 59 \\
\hline FS & 14 & 36 & 50 \\
\hline FEBI & 9 & 23 & 32 \\
\hline FITK & 54 & 82 & 136 \\
\hline
\end{tabular}

${ }^{23}$ Keputusan Rektor IAIN Walisongo tentang Mahasiswa Aktif, Lulus, Cuti, dan Dicutikan serta diberhentikan sebagai mahasiswa pada Semester Genap Tahun Akademik 2013-2014. 


\begin{tabular}{llcc}
\hline FU & 5 & 26 & 31 \\
\hline & Total & & 308 \\
\hline
\end{tabular}

Dari data tersebut diketahui bahwa mahasiswa semester tua yang ada di FITK berjumlah 136 orang. Mahasiswa tersebut pada umumnya telah selesai kuliah teori, sehingga aktivitasnya di kampus menjadi jarang. Teknik yang dilakukan peneliti untuk dapat mengumpulkan data adalah bekerja sama dengan wakil dekan bidang akademik, wakil dekan bidang kemahasiswaan dan beberapa pimpinan program studi. Wakil dekan menyebarkan undangan kepada para mahasiswa semester 12 dan 14 tersebut untuk dilakukan pembinaan, namun responsnya sangat tidak menggembirakan karena hanya ada 5 orang yang datang memenuhi undangan tersebut. Melalui pimpinan program studi, beberapa mahasiswa bisa ditemui saat mereka mengajukan judul dan atau bimbingan skripsi. Responden yang dapat direkrut dalam penelitian ini adalah 20 orang. Dengan demikian, sampling yang digunakan dalam penelitian ini adalah purposive sampling.

Data-data penelitian ini dikumpulkan dengan beberapa teknik, yakni (1) Angket, diberikan kepada mahasiswa untuk mengumpulkan data tentang problema umum yang mereka hadapi. (2) Wawancara, dilakukan kepada mahasiswa tersebut untuk mengumpulkan data lebih detail mengenai kendala-kendala yang mereka hadapi dalam penyelesaian kuliah. Wawancara juga dilakukan kepada pimpinan Fakultas terutama wakil dekan (WD) 1 dan 3 bidang akademik dan kemahasiswaan, di samping itu juga beberapa pimpinan program studi. (3) Dokumentasi, digunakan untuk mengumpulkan data tentang jumlah mahasiswa semester 12 dan 14 yang berada di FITK IAIN Walisongo Semarang, sebagaimana disajikan pada tabel di atas.

Setelah semua data terkumpul, maka dilakukan analisis data dalam bentuk analisis deskriptif naratif logis melalui pola development studies. ${ }^{24}$ Pola analisis tersebut memudahkan untuk menemukan keadaan dan tahapan-tahapan problem belajar mahasiswa. Selain itu, dapat dianalisis kemampuan mahasiswa dalam menyelesaikan perkuliahannya agar tidak mengalami drop

${ }^{24}$ Nana Saodih Sukmadinata, Metode Penelitian Pendidikan, (Bandung: Remaja Rosdakarya, 2010), hlm. 77. 
out. Di situlah akan didapatkan solusi-solusi mendalam mengenai masalah-masalah yang ditemui ini.

\section{Hasil Penelitian Dan Pembahasan}

Semua orang selalu mengharapkan untuk sukses dan lancar dalam menjalankan seluruh apa yang dicita-citakan, termasuk di dalamnya adalah pelaksanaan kuliah. Dosen bertugas untuk mengajar, mahasiswa belajar, sedangkan pihak birokrasi melayani segala proses administrasi perkuliahan sesuai aturan-aturan yang ditetapkan. Namun, selama proses berjalannya kuliah, permasalahan selalu saja terjadi. Keberhasilan dalam melaksanakan suatu tugas merupakan dambaan setiap orang. Berhasil berarti terwujudnya harapan. Perlu disadari, bahwa pada dasarnya setiap tugas atau aktivitas selalu berakhir pada dua kemungkinan: berhasil atau gagal.

1. Masalah-masalah yang Dihadapi Mahasiswa

Masalah yang dihadapi oleh mahasiswa Fakultas Ilmu Tarbiyah dan Keguruan IAIN Walisongo yang didapatkan dalam penelitian ini sangat beragam. Hal ini nampak dari kendala-kendala yang dirasakan oleh mahasiswa selama menjalankan aktivitas perkuliahan. Sejak pertama kali, mahasiswa masuk ke IAIN Walisongo dengan motivasi yang berbeda-beda. Berdasarkan data yang diperoleh, mayoritas masuk kuliah atas inisiatif diri sendiri (80\%), ada juga yang masuk kuliah karena dorongan orang tua (10\%) dan jalan keluar tidak diterima di Perguruan Tinggi Negeri lain (10\%). Ini menunjukkan bahwa masih ada $20 \%$ minat mahasiswa memilih jurusan itu bukan atas inisiatifnya sendiri, yang berpotensi menjadikannya tidak bisa merasakan basis keilmuan sejak pertama masuk kuliah. Maka dari itu, potensi untuk berkuliah dengan masalah akademik yang dihadapi terkadang muncul atas dasar dirinya merasa tidak menguasai materi-materi perkuliahan.

Data lain menunjukkan bahwa program studi pilihan mahasiswa lebih banyak dimotivasi untuk mencari ilmu (80\%), sebagian lainnya menuruti pilihan orang tua (10\%) dan alternatif prodi lainnya (10\%). Maka dari itu, ketika mahasiswa memang merasakan bahwa pilihan studinya itu tepat, perkuliahan dapat berjalan dengan baik dan lancar. Berbeda halnya dengan mahasiswa yang minat studinya atas 
dasar dorongan orang tua dan akibat pilihan alternatif, akan mengakibatkan dirinya mengalami kendala di proses perkuliahannya.

Proses penyelesaian kuliah teori dan praktik bagi mahasiswa semester tua ini sangat bervariasi. Dari selesai semester 8 s/d 14 (akhir semester masih menjalani kuliah ulang). Ini merupakan cerminan bahwa tidak semua mahasiswa mempunyai rencana kuliah yang sama akibat beban SKS yang dapat diambil berdasarkan nilai HSS yang dimilikinya. Sehingga di antara mereka ada yang bisa kuliah cepat dan ada yang merasakan kuliah dengan waktu yang sangat panjang. Dari hasil angket yang dibagikan dan wawancara dengan mahasiswa semester 12 dan 14 di lingkungan FITK IAIN Walisongo Semarang, mahasiswa menunda kelulusan mempunyai alasan: (1) Kerja, (2) Organisasi, (3) Mengajar, dan (4) Menganggur (tidak beralasan).

Data dari hasil wawancara terhadap mahasiswa semester tua yang belum selesai perkuliahannya dikarenakan berbagai hal. Dewi, jurusan PAI (Pendidikan Agama Islam) semester 13, baru saja mengajukan judul ke jurusan pada bulan September 2014. Problem penghambatnya, karena sekarang ia sudah menikah, sudah dikaruniai anak, dan tinggal di Rembang. Jarak antara Semarang dan Rembang dianggap jauh $( \pm 128$ KM $)$ sehingga sering dianggap sebagai penghambat untuk bisa melakukan komunikasi dengan kampus secara intensif.

Kasus yang sama juga dialami oleh Suasana, jurusan TBI (Tadris Bahasa Inggris). Mahasiswi semester 13 ini mengaku bahwa problem berkeluarga yang sekarang telah dikaruniai anak ini, sungguh menyita perhatian yang besar, sehingga kuliahnya merasa kurang mendapat perhatian. Jarangnya bertemu dan berkomunikasi dengan teman-teman dan juga kampus mengakibatkan ia terlelap dengan persoalan yang dihadapinya.

Hal ini dapat dimaklumi, karena ia merupakan mahasiswa pindahan dari Perguruan Tinggi lain, pada semester 13 ini ia sedang mengurus bimbingan dengan ketua jurusan Bahasa Inggris Siti Tarwiyah, dan ketika beliau dikonfirmasi oleh peneliti juga belum menunjukkan kemajuan yang maksimal. 
Berbeda dengan Fatimatuzzahro, mahasiswi PAI angkatan 2008 ini di samping memiliki problem keluarga, ia juga mengaku merasa kesulitan dalam memilih dan menentukan fokus tema skripsi. Sehingga akhirnya mundur waktunya dan baru semester ini bisa menentukan.

Hina Hilmayati mahasiswi asal Mranggen, Demak ini juga masuk kategori semester tua, sekarang ia telah masuk semester 13. Ketika ditanya tentang alasan keterlambatannya ia mengaku karena alasan keluarga. Tidak terlalu jelas alasan yang diungkapkan, tetapi secara tersirat terlihat beban ekonomi dan tanggung jawab keluarga nampaknya ikut menjadi alasan terhambatnya penyelesaian studi. Ketika ditanya sekarang tinggal di mana? Ia menjawab sekarang tinggal di Mranggen bersama keluarga. Nah, diduga jarak tempuh $( \pm 28 \mathrm{KM})$ ini mengakibatkan kurang memberikan motivasi untuk menyelesaikan studinya. Tetapi ketika ditanya tentang komitmennya, ia berusaha untuk menyelesaikan studinya semester ini.

Ma'ruf misalnya, mahasiswa semester 13 ini berbeda kondisinya. Sesungguhnya ia tergolong anak cerdas dan pandai karena ia ber-IP tinggi dan pernah dipercaya menjadi Presiden DEMA (Dewan Mahasiswa) Fakultas. Namun sampai sekarang ia belum selesai studinya. Sejak semester 7, ia sudah memulai mengembangkan bisnisnya. Jatuh bangun telah dilalui, mulai dari bisnis karet mentah, penjualan elektronik, sampai akhirnya bisnis pengembang perumahan. Saat ini ia menekuni bisnis pengembang kapling dan perumahan. Ketika dilakukan wawancara, ia berjanji untuk memberikan fokus waktu untuk menyelesaikan studinya, sehingga di akhir wawancara ia menyatakan belum mengajukan judul, sehingga fokus untuk menulis belum dimulai.

Reza Binawan mengungkapkan hambatan perkuliahannya pada aspek kemampuan untuk lulus mata kuliah, mahasiswa Tadris Biologi (TB) semester tua ini merasa kesulitan untuk menyesuaikan dengan beberapa mata kuliah, sehingga pada semester 11 ia baru lulus mata kuliah secara keseluruhan, dan di semester 12 ia baru mengikuti KKN. Tetapi karena ia berusaha bersungguh-sungguh untuk 
menyelesaikan, saat wawancara dilakukan, ia mengaku telah melakukan bimbingan skripsi bab 4 .

Adapun alasan belum lulus atau kuliah dengan waktu yang panjang (hingga berakhir 14 semester) adalah: (1) dikarenakan uang/dana sejumlah 50\% responden (kerja dan ekonomi); (2) profesi $40 \%$ responden (karier dan organisasi); (3) ambigu $10 \%$ responden (keluarga dan malas).

Rata-rata mahasiswa yang mengalami nasib berkuliah hingga masuk semester 12 dan 14 adalah bertempat tinggal di: (1) kontrak (basecamp organisasi, bareng teman-teman); (2) ikut keluarga (asal dan bantu bisnis); (3) kos (kamar dan jauh dari kampus).

Berdasarkan data-data yang didapatkan itu, maka dapat dikategorikan bahwa problem mahasiswa berkuliah dengan semester tua adalah lima hal: (1) akademik, (2) semangat, (3) finansial, (4) organisasi, dan (5) teknis.

2. Solusi yang Ditawarkan

Sudah banyak langkah penanganan percepatan kuliah bagi semester tua. Sesungguhnya penangan percepatan perkuliahan kepada para mahasiswa sudah banyak dilakukan, namun demikian belum menunjukkan hasil yang diharapkan. Di antara penanganan percepatan yang dilakukan adalah:

a. Diadakan pemanggilan oleh pihak Fakultas bagi mahasiswa semester tua. Pemanggilan ini bertujuan untuk mendapatkan laporan kemajuan (progress report) studi dan identifikasi problem yang mereka hadapi untuk dicarikan solusinya. Namun demikian dalam realitanya, pelaksanaannya berkendala dengan banyak hal, di antaranya sulitnya menghubungi mereka, dan rendahnya mereka merespons undangan yang diumumkan oleh fakultas, sehingga hanya sebagian yang hadir dalam pertemuan pembinaan mahasiswa semester tua tersebut. Di samping itu pemanggilan fakultas juga kurang dilakukan secara periodik, sehingga banyak dari mereka yang kurang tergarap.

b. Membangun komunikasi melalui jurusan (ini yang dianggap lebih efektif). Ketika dilakukan wawancara dengan sekretaris jurusan PAI, beliau menyodorkan buku tentang data mahasiswa semester tua yang belum lulus 
yang nampak tersusun rapi, seraya menjelaskan langkahlangkah yang telah beliau lakukan. Demikian juga ketika peneliti berkunjung dan wawancara dengan Ketua Jurusan Tadris Fisika, Andi Fadlan, mengatakan bahwa beberapa mahasiswa yang jumlahnya tidak begitu banyak tersebut telah kami lakukan upaya komunikasi agar mereka bisa mempercepat penyelesaian studinya. Ketua Jurusan Tadris Biologi, Listiyono, ketika ditanya terkait dengan mahasiswa semester tua yang belum lulus ini, nadanya agak serius. Karena selama ini beliau telah melakukan pendekatan kepada mereka secara maksimal, namun respons mahasiswa semester tua pada umumnya masih belum sesuai harapan. Di antara upaya yang dilakukan oleh jurusan adalah;

1) Mengidentifikasi mereka yang semester tua (semester 11/12 dan 13/12)

2) Memanggil mereka untuk dimintai laporan kemajuan studinya

3) Membantu mereka dalam menentukan fokus penelitian, sehingga bisa segera mengajukan judul

4) Memberikan pembimbing yang dianggap memungkinkan untuk mudah komunikasi lewat penunjukan pembimbing, sehingga intensitas bimbingan mereka tidak terkendala.

5) Melakukan komunikasi dengan pembimbing yang memiliki bimbingan semester tua

6) Pemberdayaan dosen wali dalam memberikan motivasi.

7) Bagi mahasiswa yang terkendala dengan mata kuliah yang belum lulus, jika waktunya masih memungkinkan, maka dibantu mengomunikasikan dengan dosen mata kuliah yang diambil.

c. Perlakuan khusus oleh dosen pembimbing bagi mahasiswa semester tua, antara lain dengan memberikan bimbingan kepada mahasiswa semester tua, Ahwan Fanani misalnya, menyediakan waktu satu Minggu sekali mengharuskan mahasiswa semester tua untuk bertemu dan melakukan bimbingan. Hal ini dilakukan dalam upaya memberikan motivasi dan dorongan agar 
mahasiswa tumbuh tanggung jawabnya untuk segera melakukan penyelesaian studinya. Mursid, dosen sekaligus Sekjur PAI juga mengaku memberikan perlakukan khusus kepada mahasiswa semester tua yang ada dalam bimbingannya. Ia mengatakan bahwa setiap Jumat, mahasiswa harus ketemu beliau untuk bimbingan, tetapi dalam realitasnya mereka belum bisa memenuhinya, karena banyak alasan. Hal yang sama juga dikakukan oleh Fakrur Rozi, dosen dan sekaligus Kajur PGMI, bahkan ia mengaku menelepon mahasiswa bimbingannya yang dianggap beberapa waktu belum menemuinya. Hal ini dilakukan agar mahasiswa yang bersangkutan bisa segera menyelesaikan tugas akhirnya.

\section{E. Pembahasan Penelitian}

Proses perkuliahan yang dilakukan dengan sistem SKS membawa dampak fleksibelnya mahasiswa untuk menyelesaikan perkuliahan. ${ }^{25}$ Walaupun jumlah beban studi mahasiswa di tiap program studi S.1 (maksimal 160 SKS.) sangat mungkin diselesaikan selama 8 semester, namun masih ada mahasiswa yang bertahan hingga semester 14. Apapun alasannya (adanya kendala internal dan atau eksternal), mereka bisa dikategorikan mahasiswa yang memiliki problem belajar.

Problem belajar pada anak normal, menurut Thomas Ziehe, dapat dilihat dari interkoneksi tiga faktor dominan yakni subyek (mahasiswa), struktur makna dan sistem makna yang dijadikan dasar untuk mengkontekstualisasikan lembaga pendidikan (program studi atau struktur pengetahuan). Hal ini dapat dipahami bahwa sebaik apapun sistem yang ada pada program studi di suatu lembaga pendidikan, jika tidak dipersepsikan positif oleh struktur dan sistem makna yang dimiliki peserta didik, maka sikap dan perilaku peserta didik tidak akan berjalan beriringan dengan sistem yang berkembang di lembaga pendidikannya (kampus). ${ }^{26}$

${ }^{25}$ IAIN Walisongo, Buku Panduan Program Sarjana (S.1) dan Diploma 3 (D.3), tahun akademik 2013-2014, hlm. 162

${ }^{26}$ T. Ziehe, Masalah Pembelajaran Norma Anak Muda dalam Konteks Sikap Dasar Kultural Dalam Knud Illeris (Ed.), Contemporary Theories of Learning (Teori-Teori Pembelajaran Kontemporer), terj. M. Khozim, (Bandung: Penerbit Nusa Media, 2011), hlm. 235. 
Untuk menghindari keteledoran mahasiswa dalam menyelesaikan tugas-tugas akademik, Dryden and Vos menyarankan agar mahasiswa dibekali kemampuan berpikir kreatif. Teknik berpikir kreatif ini dapat dibekalkan kepada mahasiswa pada masa awal studi, lalu ditindaklanjuti oleh dosen wali (pembimbing akademik) tiap semester, dilanjutkan oleh dosen pembimbing lapangan (DPL KKN-PPL) dan pembimbing skripsi saat kuliah praktek, dan ditekankan kembali secara operasional oleh pimpinan (fakultas dan atau prodi) untuk mengatasi masalah keterlambatan studi mahasiswa di semester tua. $^{27}$

Paparan di atas menunjukkan bahwa problem studi di perguruan tinggi bisa menghabiskan waktu, tenaga, dan juga biaya, di samping bisa menjadikan emosi makin tidak stabil. Oleh karena itu, penanganan problem studi tersebut hendaknya menjadi bagian dari program kerja lembaga. Apabila hal ini dapat terlaksana dengan baik niscaya problem keterlambatan studi mahasiswa dapat dicegah dan diatasi.

\section{F. Penutup}

Data-data dan analisisnya serta pembahasannya yang dideskripsikan dalam penelitian ini dapat disimpulkan:

1. Masalah-masalah yang dihadapi oleh mahasiswa semester tua adalah masalah akademik dan nonakademik. Keterlambatan penyelesaian studinya dikarenakan mereka kerja, ikut organisasi, mengajar dan menganggur (tidak beralasan).

2. Solusi yang dilakukan dalam menghadapi masalah studi mahasiswa semester tua mencakup bidang-bidang psikologis (motivasi belajar, ketahanan mental, stabilitas emosi), metodologi, finansial, organisasi dan keluarga. Penanganan problem studi tersebut dilakukan oleh pimpinan lembaga (fakultas dan program studi), dosen wali, dan dosen pembimbing. Penanganan problem tersebut dilakukan secara antisipatif (awal masa studi, orientasi akademik), preventif (selama studi oleh dosen pembimbing akademik, lapangan dan

${ }^{27} \mathrm{G}$. Dryden and Vos, J.. The Learning Revolution. (Torrance, CA, USA: The Learning Web, 1999), hlm. 183-177. 
skripsi) dan kuratif (menjelang akhir studi oleh pimpinan lembaga). Langkah-langkah ini dilakukan dalam rangka memberikan peluang kepada mahasiswa agar bisa lulus dan tidak terancam drop out.

\section{Kepustakaan}

Aghnia, "Strategi Belajar di Perguruan Tinggi", (http://aghniarahmah.blogspot.com/2011/10/strategi-belajar-di-perguruantinggi.html), diakses 10 Januari 2015.

Bunting I.J., An Education for Our Time, (Washington D.C.: Regnery Publishing, 1998).

Crawford, Alan, et.al., Teaching and Learning Strategies for Thinking Classroom, (New York: The International Debate Education Association, 2005).

Dryden, G and Vos, J., The Learning Revolution, (USA: The Learning Web, 1999).

Hakim, Abdul, "Memahami \& Menghayati Masalah-masalah Kepemudaan", (http://alhakiiim.blogspot.com/2012/11/ memahami-menghayati-masalah-masalah_13.html). Diakses: 10 Januari 2015.

http://www.nyit-nyit.net/topic/55025-cara-belajar-efektif-diperguruan-tinggi/

IAIN Walisongo, Buku Panduan Program Sarjana (S.1) dan Diploma 3 (D.3) Tahun Akademik 2013-2014.

IAIN Walisongo, Keputusan Rektor IAIN Walisongo tentang Mahasiswa Aktif, Lulus, Cuti, dan Dicutikan serta diberhentikan sebagai mahasiswa pada Semester Genap Tahun Akademik 2013-2014.

Kurniawan, Hendy, Kuliah Dibatasi Hanya 5 Tahun. http://jogja.tribunnews.com/2014/09/05/kuliah-dibatasi-hanya5-tahun/, diakses 05 September 2014.

Kurniawati, A.A., Analisis Problem-Problem Keterlambatan Penyelesaian Studi Mahasiswa di Stain Salatiga (Studi Kasus Mahasiswa Program Studi Pendidikan Agama Islam Tahun Ajaran 2004 dan 2005. http://eprints.stainsalatiga.ac.id/ 659/1/ANALISIS \%20PROBLEM-PROBLEM\%20 KETERLAMBATAN\%20PENYELESAIAN\%20 STUDI\% 20-STAIN\%20SALATIGA.pdf, diakses 1 Oktober 2014. 
Lidinillah, Abdul Muiz, Strategi Belajar Di Perguruan Tinggi (PT). (http://dindin-abdulmuiz.blogspot.com/2008/09/strategibelajar-di-perguruan-tinggi-pt.html), diakses 10 Januari 2014.

Mahmud, M.D., Psikologi Pendidikan, (Jakarta: PPLPTK, 1989).

Nadirah, Y.F. 2011. Hubungan Antara Stres dan Bersyukur dengan Keterlambatan Penyelesaian Studi pada Mahasiswa (Studi pada Mahasiswa yang Mengalami Keterlambatan Penyelesaian Studi di Fakultas Tarbiyah IAIN "SMH" Banten). http://iainbanten.ac.id/berita-314-hubungan-antarastress-dan-bersyukur-dengan-keterlambatan-penyelesaianstudi-pada-mahasiswa.html. Download 1 Oktober 2014.

Nurdiana, Aty, "Cara Belajar di Perguruan Tinggi". (http://lenterastkippgribl.blogspot.com/2013/02/cara-belajardi-perguruan-tinggi.html), diakses 11 Januari 2015.

Peraturan Menteri Pendidikan dan Kebudayaan (Permendikbud) No. 55 Tahun 2013 tertanggal 23 Mei 2013, tentang Biaya Kuliah Tunggal (BKT) dan Uang Kuliah Tunggal (UKT) pada Perguruan Tinggi Negeri (PTN) di lingkungan Kementerian Pendidikan dan Kebudayaan (Kemendikbud).

Permendikbud Nomor 49 Tahun 2014 tentang Standar Nasional Pendidikan Tinggi.

Purwanto, Ngalim, Psikologi Pendidikan, (Bandung: Remaja Rosdakarya, 1990).

Raharjo, Edzan. "Masa Kuliah Dibatasi Maksimal Hanya 5 Tahun, Mahasiswa UGM Unjuk Rasa". (http://news.detik.com/ $\mathrm{read} / 2014 / 09 / 16 / 125853 / 2691572 / 10 /$ masa-kuliah-dibatasimaksimal-hanya-5-tahun-mahasiswa-ugm-unjuk-rasa), diakses 16 September 2014.

Rooijakers, A. Mengajar dengan Sukses, terj. Soenoro, (Jakarta: Gramedia, 1982).

Rosyid, Daniel Mohammad, "Sukses Kuliah di Perguruan Tinggi. Siapa Takut?”, (http://danielrosyid.com/buku-baru-sukseskuliah-di-perguruan-tinggi-siapa-takut.html), diakses 10 Januari 2014.

Sukma, A., Studi Empiris Pengaruh Kecerdasan Emosional, Perilaku Belajar, dan Stres Kuliah terhadap Keterlambatan Penyelesaian Studi (Studi pada Mahasiswa S1 Akuntansi Universitas Brawijaya Malang), (http://jimfeb.ub.ac.id/index. php/jimfeb/article/view/707/649, diakses 1 Oktober 2014. 
336 | Raharjo

Sukmadinata, Nana Saodih, Metode Penelitian Pendidikan, (Bandung: Remaja Rosdakarya, 2010).

Ziehe, T., "Masalah Pembelajaran Norma Anak Muda dalam Konteks Sikap Dasar Kultural", dalam Knud Illeris (Ed.), Teori-Teori Pembelajaran Kontemporer, terj. M. Khozim, (Bandung: Nusa Media, 2011). 